\section{A morte de Costa e Silva e a ascensão de Médici nas narrativas de $\mathbf{O}$ Globo}

\author{
Marcio de Souza CASTILHO ${ }^{1}$
}

Resumo: $\mathrm{O}$ artigo se propõe a analisar a série de matérias "113 dias de angústia - impedimento e morte de um presidente”, de autoria do jornalista Carlos Chagas, que contribui para ilustrar, ao nosso ver, a complexidade das relações entre imprensa e estado autoritário brasileiro. $\mathrm{O}$ trabalho, publicado em 0 Globo entre 07 de janeiro e 06 de fevereiro de 1970, descreve o processo de sucessão do presidente Costa e Silva. As reportagens levaram o mesmo jornal a publicar em seguida outra série, com a versão dos chefes militares. Acreditamos que as narrativas sobre o episódio demonstram a pluralidade de papeis exercidos pelo diário durante a ditadura. $\mathrm{O}$ exame dessas questões evidencia momentos ora de distanciamento ora de recuos e conformações, que marcaram a relação entre a imprensa e o governo militar.

Palavras-chave: identidade; imprensa; narrativa

\section{La muerte de Costa e Silva y la ascención de Mé- dici en las narrativas de $\mathrm{O}$ Globo}

Resumen: El artículo tiene como objetivo analizar la serie de reportajes "113 días de angustia", escrito por el periodista Carlos Chagas, que ayuda a ilustrar, a nuestro juicio, la complejidad de las relaciones entre la prensa y el Estado autoritario del Brasil. El trabajo, publicado en O Globo entre 07 de enero y 6 de febrero de 1970, describe el proceso de transición del presidente Costa e Silva. El mismo periódico publicó otra serie, meses más tarde, con la versión de los jefes militares. Creemos que las narrativas sobre el episodio demostra la variedad de funciones desempeñadas por el periódico durante la dictadura. El examen de estas cuestiones revela momentos de distancia

1 Doutor em Comunicação e Cultura pelo Programa de Pós-Graduação da Escola de Comunicação (ECO-UFRJ). Professor adjunto do curso de Jornalismo do Departamento de Comunicação Social da Universidade Federal Fluminense (UFF). E-mail: castilhorio@terra. com.br. y conformaciones en el diálogo entre la prensa y el gobierno militar.

Palabras-clave: identidad; periodismo; narrativa

\section{Introdução}

$\mathrm{O}$ ano de 1964 foi marcado por profundas transformações no cenário político-social, que resultaram na tomada do poder por um movimento militar articulado com forças da sociedade civil. A exemplo de outras instituições da sociedade civil, a maior parte dos proprietários de jornais percebia na intervenção uma ação genuína dos militares em prol da restituição das liberdades democráticas. Órgãos da grande imprensa defenderam entusiasticamente a "Revolução de 1964", reivindicando para si o papel de protagonistas desse processo. Por isso talvez seja mais adequado falar em acordo civil-militar para a derrubada de João Goulart.

Alguns autores abordaram em suas pesquisas a atuação multifacetada da imprensa durante os 21 anos de vigência do regime militar no Brasil (1964-1985). Ao longo deste período, a relação entre o campo jornalístico e o campo político foi marcada por aproximações e distanciamentos. O esvaziamento do debate político no noticiário fornece um vasto repertório de questões sobre as relações estabelecidas entre a imprensa e o Estado durante a ditadura. Este trabalho tem o objetivo de complementar os estudos sobre a atividade jornalística neste momento histórico, delimitando a análise à série jornalística "113 dias de angústia - impedimento e morte de um presidente", do jornalista Carlos Chagas, publicada em O Globo entre 07 de janeiro e 06 de fevereiro de 1970.

A exemplo de outros campos da vida social, os jornalistas travam uma luta pelo poder para ampliar sua ação frente a outros grupos: o poder de dizer, dominar uma informação inédita, fiscalizar as ações do Estado e reivindicar o estatuto de intérprete legítimo da realidade. Optamos por examinar, num cenário de recrudescimento da repressão política, quais foram as estratégias em torno das quais Chagas negociou sentidos sobre a sua profissão.

\section{Metodologia}

Compartilhamos a visão de autores (Orlandi, Brandão) que percebem o texto inserido em práticas contextualizadas histórica e socialmente. Mais importante do que interpretá-lo numa tentativa de mostrar o que ele diz, interessa-nos verificar o processo discursivo que faz 
o texto significar. Assim, buscaremos fazer a passagem do texto para seu contexto (histórico, ideológico e político), visando identificar as relações de força neste espaço estabelecidas.

Para Orlandi, "não há compreensão sem historicidade” (1988: 74). Partindo desse pressuposto, a análise do discurso de linha francesa, que assumimos como inspiração teórica para compreensão sobre a dinâmica do funcionamento do discurso ${ }^{2}$, visa explicitar os mecanismos de produção de sentido. Tal dimensão de análise atravessa dois conceitos centrais: ideologia e discurso. Vale destacar a citação de Pêcheux utilizada pela autora para resumir o quadro teórico que alia o sócio-histórico ao linguístico: “As palavras (...) mudam de sentido segundo as posições mantidas pelo que as empregam, o que significa que elas tomam seu sentido em referência a essas posições, isto é, em referência às formações ideológicas nas quais essas posições se inscrevem" (idem: 66).

Nesta perspectiva, as formações discursivas não são unidades fechadas, imóveis, mas variam segundo as lutas ideológicas, os embates no nível político e social numa dada conjuntura. Esses fatores que colocam a exterioridade como valor fundamental determinam o que o sujeito pode e deve falar. "Por isso é que, em análise do discurso, se considera que o que define o sujeito é o lugar do qual ele fala, em relação aos diferentes lugares de uma formação social” (idem). As formações discursivas definem-se, portanto, sempre em sua articulação com as formações ideológicas.

Tais considerações sobre a análise do discurso afastam-se da perspectiva estruturalista de uma análise meramente descritiva do texto. Buscar apenas na estrutura interna dos enunciados toda a diversidade do fenômeno linguístico constitui, para Brandão (1994), uma forma redutora de perceber o texto. Não leva em conta os enquadramentos sociais e culturais aos quais os discursos estão vinculados. Na mesma linha de raciocínio de Orlandi, a autora defende um "deslocamento teórico", salientando a importância de incorporar "conceitos exteriores ao domínio de uma linguística imanente para dar conta da análise de unidades mais complexas da linguagem" (idem: 17). Brandão aponta assim para a necessidade de combinar o exame dos elementos internos com a análise do texto enquanto formação ideológica.

2 Não é nosso objetivo fazer uma análise detalhada e exaustiva das marcas lingüísticas e das operações enunciativas na leitura das reportagens premiadas.
Todas essas reflexões contribuem para o desenvolvimento de um método que situa o discurso em sua historicidade. No nosso específico, ajuda-nos a visualizar a série "113 dias de angústia" dentro de um conjunto de práticas sociais e políticas mais amplas. Seguindo esta perspectiva, fizemos a análise levando em consideração o contexto sócio-histórico, ou seja, as diferentes condições de produção em que a matéria foi produzida na conjuntura do Ato Institucional $n^{\circ} 5$.

\section{Antecedentes históricos}

O marechal Arthur da Costa e Silva assumiu o cargo de presidente em março de 1967, substituindo Castelo Branco, de quem fora ministro da Guerra. Candidato único na sucessão presidencial pela Arena - o MDB boicotou o pleito como protesto contra a manipulação eleitoral do governo - Costa e Silva teve uma gestão marcada por um período de forte agitação política na sociedade.

Líderes oposicionistas, dentre eles o ex-governador Carlos Lacerda, fortaleciam a chamada "Frente Ampla”, bloco nacional de oposição civil ao governo do marechal Costa e Silva. Carlos Lacerda buscou o apoio dos ex-presidentes Juscelino Kubitscheck e João Goulart para lançar a "Frente Ampla". O movimento tinha como objetivo redemocratizar o país e promover o desenvolvimento econômico segundo diretrizes nacionalistas.

Skidmore e Reis Filho fazem uma interessante análise ao demonstrar que a principal ameaça ao governo militar, no entanto, não vinha das esquerdas. O discurso de "subversão da ordem" servia para justificar a repressão. O que preocupava os militares era a questão das dissidências dentro dos quarteis e no interior do bloco político de direita que lhes dava sustentação. Esse aspecto ficou evidenciado no episódio envolvendo o jornalista e deputado federal Márcio Moreira Alves.

Em 3 de setembro de 1968, o discurso de Moreira Alves (MDB), criticando a invasão da Universidade de Brasília pela Polícia Militar, ocorrida no mês anterior, foi o estopim para estender as restrições às liberdades no país. Seu pronunciamento, conclamando o povo a boicotar as comemorações pelo 7 de setembro e sugerindo que as mulheres não se relacionassem com militares envolvidos na repressão, foi considerado ofensivo "aos brios e a dignidade das Forças Armadas” pelos ministros militares (CPDOC/FGV). O Congresso impediu o executivo de processar o parlamentar por seu discurso ao recusar o pedido de licença contra o deputado. A resposta do presi- 
dente veio com a edição do Ato Institucional n ${ }^{\circ}$ 5, em 13 de dezembro de 1968.

O mais violento de todos os atos da ditadura autorizou o presidente da República a decretar o recesso do Congresso Nacional e de qualquer órgão legislativo, cassar mandatos eletivos, suspender por dez anos os direitos políticos de qualquer cidadão, intervir diretamente nos estados e municípios sem os limites impostos pela Constituição de 1967, proibir manifestações públicas, confiscar bens e suspender indefinidamente o direito de habeas-corpus para crimes de natureza política.

Para o campo jornalístico, o recrudescimento da repressão causou forte impacto. $\mathrm{O}$ controle mais ostensivo sobre os conteúdos informativos teve na decretação do AI-5, em 13 de dezembro de 1968, um marco fundamental. $\mathrm{O}$ governo determina a prisão de profissionais de imprensa. Forças policiais também invadem redações do Correio da Manhã, Jornal do Brasil e veículos da imprensa alternativa. O Estado de S. Paulo e o Jornal da Tarde têm suas edições apreendidas. A Tribuna da Imprensa também passa a ser alvo constante da ação da censura. A vigilância do Estado sobre os veículos de imprensa era exercida de duas formas: autocensura e censura prévia.

A autocensura implicava na aceitação por parte dos jornais de comunicados escritos ou telefonemas dos órgãos de segurança sobre os assuntos que não deveriam ser publicados. As ordens impressas, conhecidas como "bilhetinhos", geralmente eram anônimas, de autenticidade duvidosa, e começavam com a inscrição "De ordem superior, fica proibido...”. A autocensura representava um acordo tácito entre Estado, dirigentes de jornais e produtores de notícias. Parte da imprensa seguia assim sua tradição histórica de compactuar com o poder vigente.

A censura prévia obrigava os jornais a submeter todas as notícias aos censores antes da sua publicação. Alguns chegavam a atuar na redação, vetando, na íntegra ou parcialmente, as matérias. Outros permaneciam nos órgãos encarregados por esta atividade nos estados ou em Brasília, para onde era encaminhada a edição, às custas do próprio jornal. Embora esse mecanismo de repressão tenha atingido alguns jornais entre 1968 e 1969, a sua institucionalização de fato ocorre com o Decreto-lei n ${ }^{0} 1.077$, de 26 de janeiro de 1970 (Aquino, 1999; Kushnir, 2004). Os censores enquadram atos de subversão no campo político como atentado à moral e aos bons costumes. Tudo passa a ser tipificado como risco à segurança nacional.
Essa concepção fazia da censura um ato essencialmente político.

\section{Narrativa de "vitimização"}

O trabalho do jornalista Carlos Chagas relata, em 21 reportagens, os últimos dias do presidente Costa e Silva no poder, de 27 de agosto de 1969, quando um acidente vascular agrava seus problemas de saúde, até a sua morte em 17 de dezembro do mesmo ano. A doença do militar desencadeou um conturbado processo de sucessão presidencial, que confirmaria, em outubro de 1969, o nome do general Emílio Garrastazu Médici, comandante do III Exército no Rio Grande do Sul e ex-diretor do SNI, para a Presidência da República.

O marechal Costa e Silva sofreu uma trombose cerebral, em 28 de agosto daquele ano, provocando a paralisação parcial dos seus movimentos. Embora pudesse ouvir e compreender, não podia falar. Diante da situação, uma das primeiras medidas adotadas pelos militares era excluir da disputa os quadros civis que deveriam constitucionalmente substituir o presidente enfermo. $\mathrm{O}$ vice Pedro Aleixo e demais representantes do legislativo e judiciário foram afastados das discussões sobre a sucessão. Por força de atos institucionais, uma junta militar, formada por ministros do Exército, da Aeronáutica e da Marinha, foi autorizada em 31 de agosto a substituir temporariamente Costa e Silva até a convocação de uma nova eleição. A eleição simbólica no Congresso ocorreu em 25 de outubro de 1969 sem a participação do MDB, que se absteve do pleito como forma de protesto. A posse de Médici ocorreu no dia 30 de outubro para um mandato com duração até 15 de março de 1974.

A série de $O$ Globo foi publicada em janeiro e fevereiro de 1970 já com o novo governo instalado ${ }^{3}$. Naquele ano, foi premiada com o Prêmio Esso de Jornalismo. O trabalho tem a particularidade de pertencer a um formato diferente de reportagem: o depoimento. O texto tem um tom descritivo, pontuado por relatos pessoais do autor, que era secretário de Imprensa da Presidência da República do governo Costa e Silva e, portanto, espectador privilegiado dos fatos ocorridos no gabinete presidencial e na residência oficial. $O$ jornalista realizou pesquisas, fez a checagem de dados e confrontou informações para produzir o material. No entanto, em muitos casos, não foi

3 O Estado de S. Paulo, tendo como editor-chefe Oliveiros S. Ferreira, também publicou naquele ano o trabalho produzido por Carlos Chagas em forma de artigos. 
preciso entrevistar fontes, pois boa parte dos diálogos foi resgatada a partir do esforço memorialístico do repórter.

Chagas valoriza principalmente suas impressões, o que pôde constatar ao vivenciar a rotina do presidente, os detalhes da fisionomia de Costa e Silva ao adoecer, o ambiente tenso formado em torno da sucessão presidencial e, finalmente, a reação que teve diante da morte do seu assessorado:

Estou ao lado de sua cama. Sua fisionomia é tranqüila. As mãos cruzadas sobre o peito, cabelos um pouco despenteados. E o bigode branco dos últimos tempos. (...) O Dr. Hélcio assina o atestado de óbito. O Presidente morreu de um enfarte fulminante, às $15 \mathrm{~h} 40 \mathrm{~m}$. O mal sobreveio às $15 \mathrm{~h} 30 \mathrm{~m}$, e ele perdeu a consciência quase imediatamente, apesar da medicação urgente, injeções e massagens. Seu sofrimento, ao menos na hora da morte, não terá sido tão grande. (...) A ninguém será lícito afirmar que o Presidente queria morrer, mas estava evidente que perdera todo o amor pela vida. ("Enfarte fulminante em dez minutos mata Costa e Silva”, O Globo, 06/02/1970).

O jornalista Carlos Chagas procura narrar a história cronologicamente, quase como um diário. Assim, na primeira reportagem "Causa primeira da trombose: a luta para reabrir o Congresso” (07/01/1970), ele resgata, antes do aparecimento dos primeiros sinais da doença, a intensa atuação de Costa e Silva no projeto de Reforma Constitucional de 1969. Segundo a matéria, o presidente tinha a intenção de incluir no projeto de reforma algumas medidas que contribuiriam para o processo de redemocratização, como eleições diretas para governos estaduais e a escolha do seu sucessor pelo Congresso, que estava fechado por força do AI-5:

Estava acertado que a nova Constituição seria promulgada a 2 de setembro, no Rio, para entrar em vigor no dia 7. E o Congresso, convocado a partir do dia 8. A nova Constituição vigoraria baixada por Emenda Constitucional, não por Ato Institucional mais uma prevalência de opinião do Dr. Pedro sobre o Ministro Gama e Silva. Ainda na terça-feira, à tarde, o Presidente recebeu os três Ministros Militares. (...Que os três Ministros Militares fizeram chegar ao Presidente sua discordância para com as aberturas, é fato incontestável. Mas porque o fizeram, é questão intrincada. Certamente porque representavam a mé- dia e a maioria das tendências dos principais chefes de suas corporações. Não levaram ao Presidente suas apreensões pelo gosto de impedir a redemocratização, mas como porta-vozes de uma realidade. Se a endossavam, se poderiam ter lutado para modificá-la, é outro ponto). ("Causa primeira da trombose: a luta para reabrir o Congresso”, O Globo, 07/01/1970).

Chagas reporta os acontecimentos do dia 26 de agosto, "a última noite anterior ao espectro da doença, tão próxima, agora, mas ao mesmo tempo tão distante em qualquer previsão" (idem):

O médico Hélcio Simões Gomes, que acompanhou o Presidente desde sua posse, há algum tempo que não se cansava de repetir, inclusive ao general Portela: 'O chefe anda triste. Abatido. Já não dorme bem. Seguidas vezes fica andando pelo quarto, de madrugada. Está muito preocupado'. Naquela madrugada, porém, o Presidente não teve insônia. (idem).

O enfoque de $O$ Globo associa o agravamento do estado de saúde do presidente ao contexto pouco favorável a ideias de liberalização política no fim dos anos 1960. Esse sentido está expresso no próprio título da reportagem: "Causa primeira da trombose: a luta para reabrir o Congresso". Nela, o autor escreve um texto introdutório sobre a série em que idealiza a figura de Costa e Silva, buscando dissociar a postura do militar à imagem de ditador. Nessa perspectiva, Costa e Silva doente seria vítima das circunstâncias políticas: "Um homem que chegou ao poder por força de um movimento militar, mas que, no poder, fez da integração, do desenvolvimento e da redemocratização o motivo principal da sua vida. E a perdeu essencialmente por isso" (idem).

A narrativa de $O$ Globo é trabalhada assim na perspectiva de "vitimização" do presidente. Uma das razões que ajudam a explicar o enfoque se assenta no fato de Carlos Chagas ter sido secretário de Imprensa do presidente. O jornalista assumiu essa função em maio de 1969. "É o depoimento de uma testemunha para a história", como indicou o texto da chamada de capa, na abertura da série "113 dias de angústia...”. Em depoimento publicado na edição comemorativa dos 25 anos do Prêmio Esso (1980), Chagas confirma que seu objetivo era "mostrar quem Costa e Silva realmente era, um presidente disposto a estabelecer a democracia" (idem: 95): 
Houve um objetivo em tudo isso: desfazer a imagem que o presidente Costa e Silva deixou, logo após ser afastado do governo, de mais um militar grosso e arbitrário, imagem que corria de boca em boca, pelo desconhecimento que a maioria da opinião pública tinha de sua luta, de sua tentativa para restabelecer a democracia no país. (...) Obscuros foram os que se levantaram contra a iniciativa de Costa e Silva, forçando-o e levando-o à doença e à morte, pois a trombose nada mais representou do que uma consequência de tudo isso. (1980: 94).

Um resgate histórico do governo Costa e Silva, no entanto, tende a relativizar a imagem do presidente como um "democrata". Sobre a Constituição de 1967, por exemplo, o presidente considerou a nova Carta que formalizou as mudanças por que passara a estrutura do poder a partir do golpe de 1964, com a concentração de poderes no Executivo - "moderna, viva e adequada" (CPDOC/FGV). Contudo, com a nova constituição, a ordem institucional embasada por uma legislação de exceção se sobrepôs à ordem constitucional. Em 15 de março de 1967, dia da sua posse articulada por diferentes segmentos militares, incluindo oficiais identificados com a "linha dura" do regime, foi baixado o Decreto-lei $n^{\circ}$ 314, dispondo sobre a nova Lei de Segurança Nacional e tornando todos os cidadãos responsáveis pela segurança do país. Sob o governo Costa e Silva, passou a vigorar também, em dezembro de 1968, o Ato Institucional no 5 . Segundo a matéria de $O$ Globo, o presidente "aceita o ato para evitar o pior", lamentando que faltara compreensão e apoio da classe política ("Uma falsa entrevista desencadeou o mau tempo", 04/02/1970). Em cadeia nacional de rádio e televisão, o presidente declarou, no entanto, que o ato não era "a melhor das soluções, mas sim a única" para combater "a ansiada restauração da aliança entre a corrupção e o comunismo". Sobre este instrumento que restringiu ainda mais as liberdades individuais no país, destacou ainda Costa e Silva: "Salvamos o nosso programa de governo e salvamos a democracia, voltando às origens do poder revolucionário" (CPDOC/FGV).

\section{Os antagonistas da trama}

As diversas formas de controle do Estado sobre jornais e revistas durante a ditadura militar exerceu forte impacto sobre o senso de coletividade do grupo profissional. A hostilidade do regime reconfigurou o modo de atuação dos produtores de notícias, enfraquecendo uma dada identidade em torno da qual eles buscaram historicamente legitimar o seu papel social. A noção de que o repórter está invariavelmente comprometido com a verdade, não se subordinando a nenhum outro interesse que não seja o público, forneceu historicamente as condições de aceitabilidade do discurso jornalístico. A “missão social” permaneceu como marca distintiva da imprensa, ainda que, na prática, ela atuasse como porta-voz de grupos políticos em razão das especificidades do contexto jornalístico brasileiro e seus vínculos com o poder.

Entendemos que a nova ordem política representou um "déficit" de autoridade dos profissionais de imprensa no plano político, rompendo com o conjunto de representações construídas desde o início do século XX, tais como a imagem do repórter como "cão de guarda" da sociedade. A adoção de diferentes mecanismos de cerceamento da informação, conforme expusemos acima, é indicativa das limitações e prejuízos à autonomia interpretativa do jornalista durante a ditadura.

Como reivindicar o papel de fiscalizador do poder público se o trabalho jornalístico passa a ser mediado por mecanismos de repressão? O protagonismo assumido pelos produtores de notícias como intermediários entre o acontecimento político e o público torna-se incompatível com a realidade do pós-1968. Como consequência do sistema autoritário, a perda do matiz político e ideológico rompe com o discurso denunciador da imprensa, auto-imagem que vinha sendo construída desde o início do século XX, à exceção do período do Estado Novo, como modo de legitimação da sua atuação na sociedade.

No cenário em que a atuação da imprensa esteve mediada pelo controle do Estado, outros padrões de ação foram colocados em prática para legitimação da atuação desses profissionais. Nesse sentido, quais foram as estratégias em torno das quais o jornalista Carlos Chagas negociou sentidos sobre sua profissão para compensar a perda do seu poder interpretativo no plano político?

$\mathrm{Na}$ continuidade da análise da série premiada de O Globo, podemos observar como o conjunto de reportagens de Carlos Chagas revela a complexidade das relações entre imprensa e Estado autoritário. Se por um lado, as matérias idealizam a figura de Costa e Silva dentro de uma perspectiva de "vitimização" do presidente em seu leito de morte, por outro não deixar de apresentar um discurso político que se opõe ao governo que o sucede. Veremos a seguir algumas passagens que indicam o tom um pouco mais contestatório do jornal em relação aos 
novos ocupantes do establishment político. É importante lembrar que as reportagens foram publicadas em O Globo, veículo de perfil conservador e historicamente alinhado com o regime militar, nos meses de janeiro e fevereiro de 1970, justamente durante os chamados "anos de chumbo" do governo Médici.

Nas matérias seguintes, em algumas passagens o jornalista cita o esquema de desinformação montado no Palácio do Planalto sobre a doença de Costa e Silva e comenta as retaliações que sofreu de alguns militares.

Os primeiros sinais da trombose surgiram no dia 27 de agosto durante a rotina de despachos e audiências em seu gabinete. No dia seguinte, o presidente, aconselhado por seu médico particular Hélcio Gomes, permaneceu em repouso na residência oficial. Foi quando teve início o esquema de desinformação para despistar os jornalistas que indagavam sobre a ausência de Costa e Silva no Palácio do Planalto. Os detalhes foram revelados pelo O Globo:

No Planalto, o ambiente é de rotina, mas os repórteres credenciados querem saber os motivos do cancelamento dos despachos da tarde e porque o Presidente não vem. Ligo para Rondon Pacheco. Depois, para o Alvorada. Uma forte gripe é a resposta comum, informação transmitida pelos noticiários de rádio e televisão, àquela noite. O jantar transcorreu normalmente. (...) Pouco depois, quando assistia à televisão, o Presidente foi acometido de novo insulto (o nome técnico designativo do que tivera na véspera, na presença do governador Otávio Laje). (idem)

A essa altura, o chefe do Gabinete Civil, ministro Rondon Pacheco, já havia concluído o trabalho de revisão dos originais do projeto de Reforma Constitucional. Comentara que estava tudo pronto: "Agora é rezar para que haja tempo" ("Há três anos, Costa concluía emenda”, O Estado de S. Paulo, agosto de 1972). A ideia era outorgar a Emenda no dia 2 de setembro para vigência a partir do dia 7.

Na sequência dos acontecimentos, o médico constata na madrugada do dia 29 de agosto o agravamento do acidente vascular de Costa e Silva. O próximo passo foi transferir o presidente para o Palácio Laranjeiras, no Rio, onde ele poderia receber atendimento de um especialista. A decisão partiu, segundo Carlos Chagas, do general Jayme Portella, chefe do Gabinete Militar de Costa e Silva.
Novamente, criaram-se barreiras internas para que as informações sobre o real estado de saúde do presidente não vazassem para a imprensa. Nesse trabalho de desinformação, membros da equipe do governo, como o próprio secretário de Imprensa e o ministro da Saúde, também eram despistados:

Eram cinco horas quando o Ministro Leonel Miranda, da Saúde, amigo pessoal do Presidente, é despertado em sua moderna residência da Rua Visconde de Albuquerque, no Rio. Ouve, do outro lado do fio, o relato sucinto do General (Portela), que lhe pede a convocação de um especialista em neurologia para aquela manhã, no Laranjeiras. Quer mais: que o Ministro mantenha segredo absoluto sobre o estado do 'nosso amigo comum'. Acha que ele não deve ir ao Galeão esperar o Presidente, mas levar o especialista diretamente ao Laranjeiras. A conversa continua, por metáforas, sem que o Ministro da Saúde atente bem porquê. ("Trazer o presidente para o Rio foi decisão de Portela”, O Globo, 09/01/1970, grifo nosso)

Chamamos a atenção para o fato de que revelações desse tipo eram raras na imprensa, cerceada por instrumentos como o AI-5 e outros dispositivos de controle da informação, sobretudo no início dos anos 1970. Na matéria de $O$ Globo, Carlos Chagas cita textualmente a existência de uma "cortina de fumaça" criada em torno da saúde do presidente Costa e Silva, como na passagem abaixo:

Do lado de cá, um outro mundo. Falava-se de todos os assuntos, apesar de uma expectativa incomum entre alguns membros do Gabinete Militar, justamente os que possuíam (e avaramente guardavam) informações mais detalhadas. Sabiam que o Presidente não estava bem, e que não tinha gripe. Os coroneis Massa e Covas, por exemplo, bem à minha frente, sussurravam alguma coisa importante, especialmente depois que o General Portela, aproximando-se deles, deu instruções. A operação em andamento, por enquanto, era da cortina de fumaça, e falavam das providências pedidas ao Ministro da Aeronáutica, no Galeão, para que ninguém se aproximasse do Presidente. Se outros planos começavam a esboçar-se, seria inconscientemente. (idem, grifo nosso) 
Com a decisão dos militares de substituir o presidente enfermo por uma junta formada pelos três ministros representantes das Forças Armadas, em 31 de agosto, o texto original da Emenda Constitucional foi arquivado.

Ao longo da série, Chagas aborda outros assuntos sensíveis para os militares, tais como a prisão do vice-presidente Pedro Aleixo e as crises do sequestro do embaixador americano Charles Elbrick por um grupo de guerrilheiros, além do mais áspero dos temas normalmente interditados naqueles tempos de fechamento político: a questão da censura. $\mathrm{O}$ jornalista menciona diretamente o problema da falta de liberdade de imprensa nas últimas reportagens. $\mathrm{Na} 19^{\mathrm{a}}$ matéria da série, intitulada "Uma falsa entrevista desencadeou o mau tempo" (04/02/1970), descreve, em $1^{\text {a }}$ pessoa, o ambiente criado a partir da publicação de uma reportagem do jornal La Nacion, de Buenos Aires, confirmando a existência da censura no Brasil:

Na tarde do dia 3, sou chamado ao gabinete do General Portela. Em sua companhia, o General Calderari. Portela mostra-me cópia de um recorte de jornal, do 'La nacion', de Buenos Aires.

- Você deu esta entrevista?

- Não.

Nada mais nada menos do que uma 'entrevista do Secretário de Imprensa do Governo do Brasil, protestando contra a censura estabelecida pelas autoridades militares, especialmente quanto às notícias sobre a saúde do Presidente'. Pouco depois Rondon Pacheco me procura:

- O General Lira quer saber se a entrevista é verdadeira.

- É mentirosa quanto à forma.

- Como assim?

- Não dei a entrevista. Não me caberia dá-la. Mas esse tipo de censura é um fato. $\mathrm{O}$ jornalista soube por outras fontes.

(...) As referências ao I Exército são explícitas. A situação é confusa. A temperatura, alta. ("Uma falsa entrevista desencadeou o mau tempo", O Globo, 04/02/1970, grifos nossos).

A reportagem "Rápida recuperación del presidente del Brasil”, do La Nacion, foi publicada em 03/10/1969. O jornal especula a possibilidade de escolha do nome de Médici para presidente do Brasil na impossibilidade de Costa e Silva retornar ao cargo. Especificamente sobre a questão da censura no Brasil, revelando como fonte o secretário de Imprensa Carlos Chagas, diz a nota:

El secretario de Prensa Carlos Chagas se refirió a la actual censura periodistica de todas las noticias relacionadas com la salud de Costa e Silva que no sean las contenidas em los boletines médicos oficiales. La censura, impuesta por el primer ejército, com asiento em Rio estaba destinada aparentemente a evitar las discusiones públicas sobre la possibilidad de que el presidente volviera a ejercer el cargo (...). ("Rápida recuperación del presidente del Brasil”, La Nacion, 03/10/1969).

O acirramento do embate travado entre o secretário de Imprensa de Costa e Silva e alguns setores militares era crescente. Chagas relata na série que começou a receber ameaças veladas de militares da "linha dura" para quem não bastava esvaziar suas funções dentro do governo. Pessoas mais próximas do jornalista, como Rondon Pacheco, chefe do Gabinete Civil, temiam uma retaliação mais grave. Para preservar a integridade física de Chagas, Pacheco aconselhou-o a passar um tempo em Brasília, pois ouvira do ministro do Exército, general Aurélio de Lira Tavares, que não poderia responder pela segurança do assessor no Rio de Janeiro. Havia o temor, segundo a reportagem, "que alguns extremados, à revelia de seus chefes, pudessem buscar satisfações" ("Uma falsa entrevista desencadeou o mau tempo", 04/02/1970). Com a ascensão de Médici, Chagas seria substituído por Carlos Fehlberg na Secretaria de Imprensa do governo.

\section{A versão do quartel}

A repercussão das reportagens tornou-se tão incômoda para o governo Médici que se julgou conveniente uma tentativa de contestação numa nova série publicada em O Globo entre 22 e 29 de abril de 1970. Era a versão dos chefes militares sobre a crise institucional criada a partir da doença e impedimento de Costa e Silva. As matérias foram assinadas pelo repórter Emiliano Castor. Credenciado no Ministério do Exército, ele cobria as Forças Armadas para o jornal. Segundo Chagas, a verdadeira autoria da série deve ser creditada, entretanto, ao general Antônio Carlos Murici, "o personagem mais citado no referido trabalho", que preparou "o arcabouço, as informações, os documentos e a intenção de resposta” (Chagas, 1979: 263). 
O episódio, pouco conhecido na memória da imprensa brasileira, foi criticado por vários jornalistas na época por apresentar um relato parcial, precário e tendencioso dos fatos. Ao mesmo tempo em que valoriza a biografia de personagens apresentados em outro contexto na primeira versão, o trabalho assinado por Castor tem um tom de contestação pessoal, buscando desqualificar o ex-secretário de Imprensa de Costa e Silva. O nome de Carlos Chagas é citado 56 vezes, na maior parte das vezes para corrigi-lo. Para Hélio Fernandes, "antes que os fatos se assentassem, vem o próprio ‘O Globo' e, querendo prestar serviço aos que não gostaram da primeira versão, procura destruir tudo que serviu ao trabalho de Carlos Chagas, para montar em seu lugar uma nova versão, essa sim parcilíssima e interessada, pois composta deliberadamente" (Fernandes, apud Chagas, 1979: 246).

Como outros jornais, O Globo oscilou momentos de aproximação e distanciamento em relação ao Estado autoritário, com predominância para o primeiro. Se a matéria de Chagas ensaiou, não premeditada ou intencionalmente, um afastamento do discurso oficial, a série de Emiliano Castor ou do general Murici evidencia recuos e conformações.

\section{A morte da notícia}

Com a série de reportagens "113 dias de angústia - impedimento e morte de um presidente", Chagas foi agraciado com o Prêmio Esso de Jornalismo em 1970. Em 21 de dezembro daquele ano, durante a solenidade de entrega da premiação, fez um discurso, no salão nobre do Hotel Glória, condenando a censura à imprensa e o processo de "subversão não apenas do jornalismo, mas dos princípios elementares da ética e da moral que deveriam reger a sociedade" (Chagas, 1979: 251).

Nos sistemas totalitários, nos regimes de exceção, da esquerda ou da direita, a notícia nada mais é do que um agente a serviço do Estado, ou melhor, dos interesses e das idiossincrasias dos homens ou dos grupos que em determinado momento dirigem o Estado. Torna-se a antinotícia, pois quando lhe permitem aparecer nas manchetes, nas colunas, nos microfones ou nos vídeos, ela reflete o oposto da realidade dos fatos, ela invariavelmente traz a meia-verdade, ou até a mentira integral. No entanto, não se situam apenas na extrema direita ou na extrema esquerda os algozes da notícia. Especialmente nos países em desenvolvimento, ainda sem estruturas sociais completas, notamos acentuar-se um fenômeno que igualmente envolve, torce, viola e degrada a notícia: a influência de grupos que estabelecem a ditadura de seus interesses e não raro transformam os veículos e as próprias notícias em trampolim para seus objetivos. Não necessito dar exemplo de nenhum dos casos. A realidade está à vista de todos. ${ }^{4}$

Associando democracia à imprensa livre, Carlos Chagas afirmou que todos os jornalistas deveriam lutar pela sobrevivência da notícia para que pudessem sobreviver como profissionais. Criticou também o processo de autocensura, reafirmando a importância de a imprensa assumir uma postura de dignidade e resistência pela manutenção da liberdade de expressão: "que não caiba, pelo menos a nós, jornalistas, qualquer ônus pelo vilipêndio da notícia. Que outros assumam a tarefa de torcer, inverter, reduzir ou omitir" (Chagas, 1979: 252). Tal mobilização teria contribuído para o processo de institucionalização da censura prévia no país. Reproduzimos a seguir outra passagem do discurso:

Assistimos, hoje, senão à morte, ao menos à enfermidade da notícia, por inanição. Nós, que somos cultores da notícia, que dela vivemos e para ela vivemos. Quando a notícia é reprimida, é a nós que estão reprimindo. Quando a notícia é sufocada, é a nós que estão sufocando. E não creio que nos caiba, como classe ou indivíduos, apenas o papel de sufocados e oprimidos. Cabe-nos, companheiros, agora mais do que nunca, lutar pela sobrevivência da notícia - a nossa própria sobrevivência, e da sociedade, à qual servimos. Cabe-nos deixar bem claro, ao menos, que ofende a liberdade o fato de indivíduos, grupos ou classes pretenderem situar-se acima e além da sociedade, acima e além das notícias, imunes a elas mesmo quando as estão produzindo e, com fartura, atos e fatos geradores dessas notícias. Cabe-nos deixar bem claro, ao menos, que ofende a verdade a pretensão dos que, depois de chamarem a si a direção e os destinos da sociedade, julgam que seus atos, suas querelas, suas crises, seus erros e seus acertos devem permanecer no limbo, sem divulgação, como se não dissessem respeito, também, à sociedade que passaram a dirigir. ${ }^{5}$

4 Trecho do discurso de Carlos no Hotel Glória, em solenidade de entrega do Prêmio Esso, dezembro de 1970.

5 Idem 
Se os instrumentos de controle da produção noticiosa limitaram e causaram prejuízos à autonomia do jornalista durante a ditadura, o discurso de Carlos Chagas pode ser lido como tentativa de resgate de uma dada identidade profissional caracterizada por um discurso denunciador contra o poder político. O premiado utilizou o evento como tribuna para denunciar a violação de direitos humanos e criticar a censura e a falta de liberdade de imprensa.

Em maio de 1970, Chagas transformou as reportagens em livro, acrescentando dados e corrigindo eventuais erros na primeira série de $O$ Globo. A obra, no entanto, só foi editada e impressa em dezembro daquele ano, pois o autor encontrou uma série de dificuldades para publicá-la. Um dos obstáculos foi conseguir uma editora que aceitasse levar o projeto adiante. Com medo de represálias, alguns editores recusaram a solicitação para não confrontar o governo Médici. Yedo Mendonça, proprietário da Editora Image e amigo de Chagas, aceitou fazer o lançamento. Na primeira semana, foram vendidos dois mil exemplares somente no Rio de Janeiro. Porém, quando a distribuição começava a chegar em outros estados, os livros foram apreendidos por ordem direta do ministro da Justiça, Alfredo Buzaid, a despeito da autorização do general Luiz Carlos Reis de Freitas, da Polícia Federal, em 23/09/1970. Buzaid advertiu que Chagas estava incurso na Lei de Segurança Nacional "por contar o que não devia, ou não podia” (Chagas, 1979: 21). O livro "113 dias de angústia - impedimento e morte de um presidente” só voltou a ser reeditado em 1979 , no período da abertura política, pela L\&PM editores.

\section{Múltiplas identidades da imprensa}

$O$ contexto da ditadura militar marcou um processo de esvaziamento do debate político na imprensa brasileira, com o cerceamento do conteúdo noticioso através da prática da censura e da autocensura. Isso não significa dizer que houve um processo por completo de despolitização dos profissionais de imprensa, visto que a questão ideológica estava presente nos anos 1960 e 1970 e o Estado como "inimigo" ainda animava um espírito contestador dentro das redações.

Entendemos não haver surpresa um jornalista decidir escrever uma matéria, na condição de ex-assessor de imprensa, valorizando as ações do seu antigo assessorado, com quem mantinha uma relação de admiração e amizade. Apesar do fechamento político, o processo de idea- lização de Costa e Silva não se constituía propriamente numa ameaça aos militares ligados ao presidente Médici que assumia o comando do país. Convém destacar, no entanto, que o sentido de "vitimização" do ex-presidente pressupõe personagens antagonistas na trama narrativa. Se ele foi vítima, coube aos ministros militares que conduziram Médici ao posto de mandatário da nação a figura de “algozes" ou "vilões" na história de "113 dias de angústia...”. Esses mesmos personagens estavam no poder quando foi lançada a série jornalística e, não obstante, a conjuntura era de forte repressão aos órgãos informativos, como demonstram diversas pesquisas que tratam da história da imprensa no país. $\mathrm{O}$ exame dessas questões mostra, portanto, que a análise sobre a ditadura militar no Brasil vai além dos reducionismos ou generalizações abstratas que tendem a compartimentar a história em períodos estanques, os mais brandos e os mais violentos, ou indivíduos sem história social, vivendo fora do seu tempo ou da conjuntura específica.

O mesmo raciocínio vale para o campo jornalístico. Inserida nesta sociedade e como ela marcada por ambiguidades, a imprensa e outras instituições da sociedade civil não estiveram à margem do processo de transformações no cenário político-nacional. Não há necessariamente uma contradição no fato de $O$ Globo, jornal de linha conservadora, beneficiado em vários momentos por sua proximidade com o poder militar, publicar uma série de matérias de cunho político contra os aliados de Médici que levaram indiretamente Costa e Silva para o caminho irreversível da doença e da morte, como denota a narrativa de Carlos Chagas. É questão controversa acreditar ser possível traçar uma linha divisória apontando determinados jornais da grande imprensa como veículos que atuaram permanentemente na resistência e jornais conservadores como órgãos de divulgação do Governo. Há momentos em que os papeis se invertem, mostrando a complexidade das relações entre imprensa e Estado autoritário. A análise da matéria de Chagas em $O$ Globo nos chamados "anos de chumbo" contribui para ilustrar a precariedade dessa lógica maniqueísta.

O exame dessas questões demonstra que o jornalismo brasileiro é muito heterogêneo em torno do seu papel funcional e ideológico. Há uma pluralidade de papeis exercidos pelos produtores de notícias. As identidades são organizadas dentro de um permanente processo de interação e intercâmbios sociais, estabelecendo, de acordo com os processos históricos, novas relações de poder. 
Diante da pluralidade e diversidade de versões, não temos a pretensão de esgotar todas as possibilidades de interpretação sobre o papel assumido pelos produtores de notícias durante o regime militar. O que propomos é complementar, através da análise da matéria de Carlos Chagas, outros estudos de identidade jornalística a partir da fluida relação entre imprensa e Estado autoritário brasileiro.

\section{Referências:}

ALVES, Marcio Moreira. Marcio Moreira Alves II (depoimento, 1997). Rio de Janeiro, CPDOC/ALERJ, 1998, p. 7

AQUINO, Maria Aparecida de. Censura, Imprensa, Estado Autoritário (1968-1978): o exercício cotidiano da dominação e da resistência O Estado de São Paulo e Movimento. Bauru: Edusc, 1999.

BARBOSA, Marialva. História cultural da imprensa: Brasil, 1900-2000. Rio de Janeiro: Mauad X, 2007.

BRANDÃO, Helena H. Nagamine. Introdução à análise do discurso. Campinas, SP: Unicamp, 1994.

CARNEIRO, Maria Luiza Tucci. Minorias silenciadas: história da censura no Brasil. São Paulo: Edusp, 2002.

CHAGAS, Carlos. 113 dias de angústia - impedimento e morte de um presidente. Porto Alegre: L\&PM Editores, 1979.

LUZ, Olavo e BORGES, Manoel (org.). 25 anos de imprensa no Brasil - Prêmio Esso de Jornalismo. 1980.

KUSHNIR, Beatriz. Cães de guarda - Jornalistas e censores, do AI-5 à Constituição de 1988. São Paulo: Boitempo Editorial, 2004.

MARCONI, Paolo. A censura politica na imprensa brasileira, 1968-1978. São Paulo: Global Editora, 1980.

REIS FILHO, Daniel (Org). "Ditadura e sociedade: as reconstrucões da memória”. In FICO, Carlos, CASTRO, Celso, QUADRAT, Samantha, et all (orgs.). 1964-2004: 40 anos do golpe: ditadura militar e resistência no Brasil. Rio de Janeiro: 7Letras, 2004. pp. 119-139.
SKIDMORE, Thomas E. Brasil: de Castelo a Tancredo, 19641985. Rio de Janeiro: Paz e Terra, 1988.

SMITH, Anne-Marie. Um acordo forçado - O consentimento da imprensa à censura no Brasil. Rio de Janeiro: Fundação Getúlio Vargas, 2000.

ZILBERMAN, Regina e SILVA, Ezequiel Theodoro da (Org.). "O inteligivel, o interpretável e o compreensivo". In: Leitura: Perspectivas interdisciplinares. São Paulo: Editora Ática, 1988.

Matérias analisadas

O Globo (07/01/1970): "Causa primeira da trombose: a luta para reabrir o Congresso"

O Globo (08/01/1970): "Crise inicial e o propósito de só descansar depois do dia 8”

O Globo (09/01/1970): “Trazer o presidente para o Rio foi decisão de Portela”

O Globo (04/02/1970): "Uma falsa entrevista desencadeou o mau tempo"

O Globo (05/02/1970): “Ato impede Presidente e abre o Congresso: Médici empossado”

O Globo (06/02/1970): "Enfarte fulminante em dez minutos mata Costa e Silva"

La Nacion (03/10/1969): "Rápida recuperación del presidente del Brasil”

O Estado de S. Paulo (agosto de 1972) "Há três anos, Costa concluía emenda"

Recebido: 08/07/2012

Aprovado: 18/09/2012 